\title{
The Schools' Evaluation Portfolio Characteristics for KURTILAS
}

\author{
Nurmawati ${ }^{1}$, Fenny Anggreni ${ }^{2}$, Nuraida $^{3}$ \\ \{nurma16@ymail.com¹, aidanur2@gmail.com ${ }^{3}$ \} \\ ${ }^{1}$ Department of Mathematics Education, IAIN Langsa, Meurandeh Street, Langsa, Indonesia \\ ${ }^{2}$ Department of Kindergarden Teacher Education, IAIN Langsa, Meurandeh Street, Langsa, Indonesia \\ ${ }^{3}$ Department of Primary Teacher Education, IAIN Langsa, Meurandeh Street, Langsa, Indonesia
}

\begin{abstract}
Evaluation is quantified measurements based on the portfolio of curriculum objective. The Article investigated about KURTILAS portfolio measurements system in order to improve the quality and quantity of educational institutions as its core program productivity. The 13th National Standard Curriculum (KURTILAS) emphasizes modern pedagogical approaches that based on scientific within the subjects delivery, i.e. Observations, Questioning, Association, Experimenting, and Networking. The Article excluded the KURTILAS portfolio measurement system evaluation influenced for these following dimensions; characteristic, knowledge, and skill. Then, the deliver evaluation results increase students with senses of productive, creative, innovative and affective within the integrated strengthen KURTILAS dimensions abovee
\end{abstract}

Keywords: Evaluation Portfolio, KURTILAS.

\section{Introduction}

Evaluation is measurement systems. It exposes calculation and scoring. Evaluation is also quantified assessments process to validate the result of evaluation. It is a part of consideration decision taking for good or bad qualitatively influences. Evaluation is, also known as measuring and assessing, defined with size and quantitative achievements as feedback for building strong foundation in educational world. The curriculum philosophical approach in educational raised a challenge about the reliability gap to construct a valid evaluation. It concerns about to measure the objects (students' achievement) within schools as institution and teachers as the educators. The difficulty of evaluation pulls in a lot of basic cognitive process as it distinctly demonstration a link between a student's action and his occupation advancement. Opposite evaluation systems have been used for more than 60 years all over the world. [1].

Evaluation was executed with numerous and theoretical approach. It derived the seventh concepts of scientific evaluation. i.e. philosophy, psychology, communication, curriculum, management, and socio-anthropology. Within philosophy approach educational evaluation related to the fundamental issues about approach and method evaluation necessity and delivery. Moreover, its psychological effects are about difficulty level consideration which is reliable to students' skills and lesson objectives as well. The reliable evaluation suits contents to delivery as feedback and achievements. The evaluation systems are essential in educational achievement as mean of assessment or measurement. Literally, the word evaluation, 
measurement and evaluation are identified as to assess. Moreover, the activity measure is included as evaluation to measure, assess, and evaluate as integration process. It is an activity that cannot be separated from one another, and the implementation must be done sequentially. The article projected the approaches and method of portfolio evaluation on KURTILAS for school institutions.

\section{Portfolio Evaluation}

Portfolio evaluation is an accumulation of the best illustration of student's activity. A portfolio is a meaningful accumulation of pupil activity that evidence the student's attempt, advancement, and accomplishment in one or more than domain ([2]. A portfolio in the context of the teaching-learning is a collection of student works that information skilfulness of a set of ability, practical knowledge, and mental attitude.

The various works in a portfolio are frequently mentioned to as "artefacts". Artefacts appearance: Unit demonstration principally demonstrates learners' progression. Procedure directed portfolios indicate to each the narration of the development of the student: they include a student's product from the occurrent to the extremity of the tilted portion. Public exhibition is a final common element of both kinds of portfolios. Circumstantial to under consideration education theories, portfolio supported learning could be perspective as inhabit the advanced form of cognition and ability combination. in that learners would be meditating on the improvement of all of their professional skills in the cognitive process of moving their sudden professional personal identity [3]. Student activity from the portfolio improvement procedure indicates that the process itself successful them more awake of their own learning activities and how they necessary to issue criterion of their learning action to variety them more purposeful for individual and professional development.

\section{Text formatting}

The main text should be written using Times New Roman, 10pt, fully justified. Italics can be used for emphasis and bold typeset should be avoided.

\section{KURTILAS}

Kurikulum Tiga Belas (KURTILAS), The 13th national standard curriculum issued on the in 2013 by the Ministry of Education and Culture for schools in Indonesia. It is implemented from Undang-Undang No. 20 Thn 2003 about the National standard in educational Definition and Systematic; its contexts, plans, objectives, lesson plan, and so on. Undang-Undang No. 20 Thn 2003 also stated about the dimensional of curriculum within the school units; the lesson plan and its objective, contents, and subject delivery; the approach and method in teachinglearning (“PERMENDIKBUD NOMOR 69 TAHUN 2013,” 2013). 
KURTILAS main objective is settled improve Indonesian' live quality with religiously faith perspective, productive, creative, innovative, and affective. It also is directed to contribute for national empathy for nation, country, and civilization. The concepts of KURTILAS are featured as follow:

1. KURTILAS evokes three domains i.e. Characteristics, Knowledge, and Skill. These domains projected the students' integrated self-enhancements of productive, creative, innovative, and affective.

2. KURTILAS characteristic domain transforms learning material to be critically "WhyKnow"

3. KURTILAS Skills domain transforms learning material to be critically "How-Know"

4. KURTILAS Cognitive domain transforms learning material to be critically "What-Know"

5. KURTILAS projects feedback about balance in characteristic and skill with supported soft skill and hard skill for live quality of the students within characteristic, knowledge, and skill.

In Modern pedagogics approach, KURTILAS emphasized scientific approach; it concerns about observing, questioning, associating, experimenting, and networking.

\section{Kurtilas Evaluation Domain}

In Chapter 27, Act 2 of Undang-Undang No. 20 Thn. 2003, the evaluation objectivity domain in KURTILAS identified as lesson, program, and system evaluation. It concerns about the students-teacher, institution, and educational objective. It also concerns about formal and non-formal layer of educational institution unit.

Evaluation is the core process of teaching-learning feedback delivery. It evolves extended layers from curriculum to program assessment, i.e. program's implementations and affectivities. The domain perspectives exclude learning feedback and process as mentioned by Benjamin S. Bloom. The domains are projected as follow:

1. Cognitive has been revised by Anderson \& Krathwohl in 200, it includes remember, understanding, applying, analyzing, evaluating and creating [5]

2. Taxonomy bloom was later re-developed by Krathwohl, Bloom, and Masia 1956 by adding a domain called Affective, it includes receive, respond, value, and organization [6] .

3. Psychomotor, it includes operational and execution. Psychomotor extend the its domain into three branches;

a. Muscular or motoric skill; it includes movement, performance, result, jump, and motions

b. Object material s manipulation, it includes fixing, structuring, cleaning, moving, and shaping,

c. Neuromuscular coordination; it includes observe, implement, joints, pairing, cutting, and applications. 


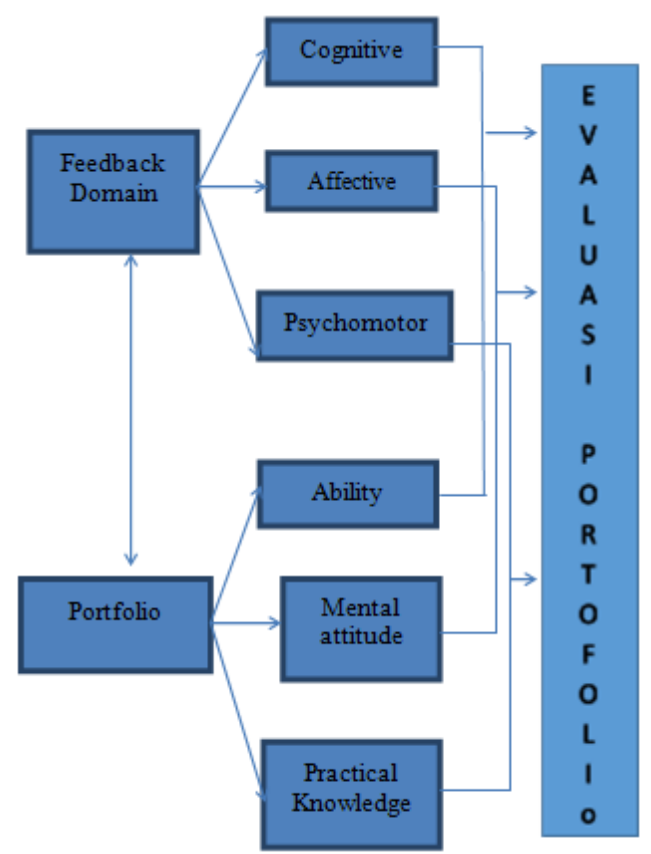

Figure 1. The correlation of Learning Feedback and Portfolio Evaluations

\section{Kurtilas Measurements Dimension of Evaluation Portfolio}

The weakness of previous KTSP curriculum basically indicated on the faded domain of affective, cognitive and psychomotor. Moreover, KTSP degraded these domains by skipping within teaching-learning materials. In other hand, it neglected human characteristic for testing and presume the superiority of cognitive to affective and psychomotor. To meet this weakness, KURTILAS was introduced on 2013 as modern pedagogic with scientific approach as the main catalyst in teaching-learning process [7]. The Scientific approach is the essential foundation to formulate methodology that resembles in strategy and technique for teachinglearning experiences of KURTILAS characteristics. In addition, there are three pillars of scientific approach within KURTILAS i.e. active learning, assessments, and diversity. It enables the students to work and observe phenomena of lesion that presented in videos, pictures, mind-setts, texts, natures, and so on.

The KURTILAS implements scientific approach by reaching these three domains; affective, cognitive and psychomotor. The government expects KURTILAS improve student's creativity, innovative, well-balance between soft skills; include about moral favor, knowledge, and hard skill with integrated personality improvement. 


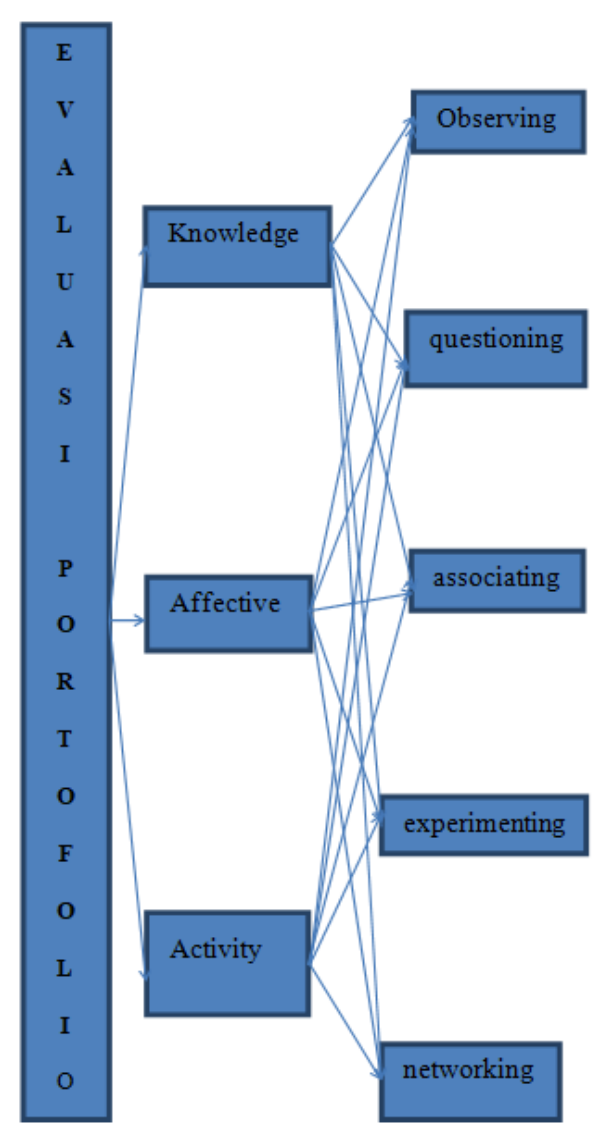

Figure 2. The Dimension of KURTILAS Portfolio Evaluation

\section{Conclusion}

The evaluation is actually a feedback for improvement and achievement both teacherstudents and institution. Educational develop and evolve the human by considering the basic objective is to educate people to be better one. Evaluations, when it posted as test, play an important role to assess the executed program and organizations.

\section{Acknowledgment}

Alhamdulillah, all praises to Allah for the strengths and His blessing in completing this thesis. And peace be upon him, our prophet Muhammad saw, the one who brings us a light of Islam as faith and mindset, the way of ibadah to Allah swt, the way of creation in our life. Our first gratitude is credited to all the research beneficiaries, who gave us chance to contribute in researching about educational curriculum and research projects. Finally, we would declare that 
this study is a beginning of new breakthrough in finding sustainability systems in educational world.

\section{References}

[1] A. I. Sherstneva, O. N. Imas, N. Y. Galanova, and T. Van Tuan, "Influence of Evaluation System on Effectiveness of Foreign Students' Mathematical Education," Procedia - Soc. Behav. Sci., vol. 215, no. June, pp. 181-184, 2015.

[2] Q. Zhan and L. Zhang, "Principles and a framework of performance evaluation for learners in distance vocational education,” Procedia Eng., vol. 15, pp. 4183-4187, 2011.

[3] F. Iofciu, C. Miron, and S. Antohe, "Constructivist approach of evaluation strategies in science education,” Procedia - Soc. Behav. Sci., vol. 31, no. 2011, pp. 292-296, 2012.

[4] "PERATURAN MENTERI PENDIDIKAN DAN KEBUDAYAAN REPUBLIK INDONESIA NOMOR 69 TAHUN 2013,” 2013, pp. 2013-2015.

[5] C. Starr, B. Manaris, C. W. Starr, B. Manaris, and R. H. Stalvey, "Bloom â€TM s taxonomy revisited: Specifying assessable learning objectives in computer science Bloom's Taxonomy Revisited: Specifying Assessable Learning Objectives in Computer Science," Conf. Pap. ACM SIGCSE Bull., no. January, 2008.

[6] W.Huitt, "Bloom et al.'s Taxonomy of the Cognitive Domain,” Educ. Psychol. Interact., 2011.

[7] M. F. Atsnan and R. Y. Gazali, "PENERAPAN PENDEKATAN SCIENTIFIC DALAM PEMBELAJARAN MATEMATIKA SMP KELAS VII MATERI BILANGAN ( PECAHAN )," Pros. Semin. Nas. Mat. dan Pendidik. Mat., no. November, pp. 978-979, 2013. 